\title{
An MMP-2/MMP-9 inhibitor, 5a, enhances apoptosis induced by ligands of the TNF receptor superfamily in cancer cells
}

\author{
O Nyormoi ${ }^{1}$, L Mills ${ }^{1}$ and M Bar-Eli ${ }^{*, 1}$ \\ 1 Department of Cancer Biology, The University of Texas MD Anderson Cancer \\ Center, 1515 Holcombe Boulevard, Houston, TX 77030, USA \\ * Corresponding author: M Bar-Eli, Department of Cancer Biology, The \\ University of Texas MD Anderson Cancer Center, 1515 Holcombe Boulevard, \\ Houston, TX 77030, USA Tel: +1-713-794-4004; Fax: +1-713-792-8747; \\ E-mail: mbareli@mdanderson.org
}

Received 4.9.02; revised 9.10.02; accepted 25.10.02

Edited by ME Peter

\section{Abstract}

Several studies have shown that matrix metalloproteases (MMPs) promote tumor growth, invasion, and metastasis. Consequently, MMP inhibitors have been developed as a new class of anticancer drugs, many of which are in clinical trials. The exact mechanism of the antineoplastic activity of MMP antagonists is unknown. To investigate the mechanism, we hypothesized that MMP inhibitors enhance the actions of apoptosis-inducing agents. To test this hypothesis, we treated breast, melanoma, leukemia, osteosarcoma, and normal breast epithelial cells with (2R)-2-[(4-biphenylsulfonyI)amino]-3-phenylproprionic acid (compound 5a), an organic inhibitor of MMP-2/MMP-9, alone or in combination with TNF $\alpha$ or other apoptotic agents. FACS analysis showed that 5a interacted synergistically with ligands of the TNF receptor superfamily, including TNF $\alpha$ and TNF receptor-like apoptosisinducing ligand (TRAIL), and with a Fas-cross-linking antibody (CH11), UV, paclitaxel, thapsigargin, and staurosporin, to induce apoptosis in a cell-type-specific manner. Other MMP inhibitors did not synergize with TNF $\alpha$. Compound 5 a did not act directly on the mitochondrion or via changes in protein synthesis. Instead, the mechanism requires ligandreceptor interaction and caspase 8 activation. Investigation of the effect of $5 \mathrm{a}$ on tumor growth in vivo revealed that continuous treatment of subcutaneous melanoma with a combination of 5 a plus TRAIL reduced tumor growth and angiogenesis in nude mice. Our data demonstrate that $5 \mathrm{a}$ possesses a novel proapoptotic function, thus providing an alternative mechanism for its antineoplastic action. These observations have important implications for combination cancer therapy.

Cell Death and Differentiation (2003) 10, 558-569. doi:10.1038/ sj.cdd. 4401209

Keywords: apoptosis; matrix metalloproteinase inhibitors; synergy; receptor; tumor growth

\begin{abstract}
Abbreviations: MMP, Matrix metalloproteinase; MMPI, matrix metalloproteinase inhibitor; FACS, flow-activated cell sorter; MTP, mitochondrial transmembrane potential; SODD, silencer of death domain; FADD, Fas-associated death domain; TNF $\alpha$, tumor necrosis factor alpha; PBS, phosphate-buffered saline; SDS-PAGE, sodium dodecyl sulfate polyacrylamide gel electrophoresis; RIPA, radioimmune precipitation; TRAIL, TNF receptor-like apoptosis-inducing ligand; $E C L$, enhanced chemiluminescence; $\mathrm{DiOC}_{6}$, 3,3-dihexyloxacarbocynine iodide; IPA, inhibitor of apoptosis protein; FLIP, Flice-inhibiting protein.
\end{abstract}

\section{Introduction}

One of the critical issues in cancer treatment today is that many tumors become resistant to single-agent therapy. 1,2 Combination therapies have been developed to address this problem, ${ }^{3-7}$ but some tumors still respond poorly to combination therapies, suggesting the existence of some yet unknown molecular variations that are not targeted by such therapies. ${ }^{8}$ Consequently, there is a need to identify critical molecular characteristics of cancer cells that would guide the development of new cancer therapies. In this regard, the propensity of tumor cells to invade normal tissues and metastasize to distant sites $^{9}$ is promoted by matrix metalloproteinases (MMPs), which are zinc-dependent endopeptidases that degrade extracellular matrices. ${ }^{10-13}$ Consequently, in recent years much attention has been focused on developing MMP inhibitors (MMPIs) as a new class of anticancer drugs. Several of the MMPIs have been reported to possess antineoplastic activities. $^{14,15}$ Some of them are presently at various stages of clinical trials. ${ }^{16-21}$

While the antineoplastic activity of MMPIs is presumed to be because of the inhibition of MMP enzymes, the exact mechanism is not yet completely understood. Some studies reported that MMPs promote tumor growth by releasing growth factors from their inactive membrane-bound form, ${ }^{22-24}$ suggesting that MMP antagonists would inhibit cell growth, while other studies have reported that MMPIs inhibit tumor proliferation by inducing apoptosis via the release of ligands such as TRAIL and TNF $\alpha$ from their membrane-bound inactive forms. ${ }^{25}$ Furthermore, MMPIs have been implicated in the inhibition of shedding of stress-induced membranebound receptors. ${ }^{26-29}$ However, these studies have not yet clearly elucidated the exact mechanisms by which MMPIs antagonize tumor growth, invasion, and metastasis.

In the present study, we hypothesized that MMPIs modulate the expression or function of proteins involved in the induction of apoptosis. We tested this hypothesis by treating breast, melanoma, leukemia, and normal transformed cells with (2R)-2-[(4-biphenylsulfonyl) amino]-3-phenylproprionic acid (5a), ${ }^{30,31}$ an MMP-2/MMP-9 inhibitor derived from $N$-sulfonylamino acid, to determine whether it would enhance apoptosis 
induced by ligands of the TNFR receptor superfamily. We report here that $5 \mathrm{a}$ interacted synergistically with ligands of the TNF receptor superfamily to enhance apoptosis in cancer cells in a cell-type-specific manner and that combination treatment reduced tumor growth and angiogenesis in vivo.

\section{Results}

\section{Effect of compound 5a on TNF $\alpha$-induced apoptosis}

To investigate the mechanism of antineoplastic activity of MMPIs, we treated 9D3S breast cancer cells with $0.2 \%$ DMSO alone, $200 \mathrm{nM} 5 \mathrm{a}$ alone, $20 \mathrm{ng} / \mathrm{ml} \mathrm{TNF} \alpha$ alone, and $200 \mathrm{nM} 5$ a followed by $20 \mathrm{ng} / \mathrm{ml}$ TNF $\alpha$. FACS analyses of DNA fragmentation, a measure of cell death, showed that neither $0.2 \%$ DMSO, nor $200 \mathrm{nM} 5 \mathrm{a}$, nor $20 \mathrm{ng} / \mathrm{ml} \mathrm{TNF} \alpha$ alone induced significant cell death after 12-20 h (Figure 1a, panels $1-2,3-4$, and 5-6). In contrast, 5a enhanced the apoptotic effect of TNF $\alpha$ by 3-10-fold (Figure 1a, panels 7-8). In the presence of $5 \mathrm{a}, \mathrm{TNF} \alpha$-induced cell death was accelerated and reached a maximum level within $12-20 \mathrm{~h}$ instead of $48 \mathrm{~h}$, as we previously demonstrated. ${ }^{32}$ It should be noted that adding $\mathrm{TNF} \alpha$ before $5 \mathrm{a}$ had the same effect as adding TNF $\alpha$ alone.

We next determined the optimum preincubation time necessary to achieve synergy. As shown in Figure 1b, adding $\mathrm{TNF} \alpha$ simultaneously with $5 \mathrm{a}(0 \mathrm{~h})$ or 5 and $6 \mathrm{~h}$ after preincubation with 5 a was less effective in enhancing apoptosis than adding $\mathrm{TNF} \alpha 1-3 \mathrm{~h}$ after the cells were preincubated with $5 \mathrm{a}$. Subsequently, we tested whether the failure of $5 \mathrm{a}$ to synergize with $\mathrm{TNF} \alpha$ following $5-6 \mathrm{~h}$ of preincubation might be because of a depletion of $5 \mathrm{a}$. To that end, at the 5 and $6 \mathrm{~h}$ time points, we treated cells with additional DMSO, 5a, TNF $\alpha$ alone as before, or 5 a followed by $\mathrm{TNF} \alpha 1 \mathrm{~h}$ later. We found that additional DMSO, $5 \mathrm{a}$, and TNF $\alpha$ alone had no effect on cell death, whereas the addition of $5 \mathrm{a}$ followed by $\mathrm{TNF} \alpha$ restored synergy between $5 \mathrm{a}$ and $\mathrm{TNF} \alpha$ (Figure 1b, columns 5+ and 6+).

Furthermore, we investigated the effect of 5 a concentration needed to synergize with TNF $\alpha$ to induce apoptosis. As shown in Figure 1c, 200-400 nM 5a alone did not induce cell death (columns 200, 300, and 400). We next determined whether simultaneous treatment of cells with higher concentration of $5 \mathrm{a}(300$ and $400 \mathrm{nM})$ and $20 \mathrm{ng} / \mathrm{ml}$ of TNF $\alpha$ would enhance apoptosis. Figure 1c shows that $300 \mathrm{nM} 5 \mathrm{a}$ added simultaneously with $20 \mathrm{ng} / \mathrm{ml}$ of TNF $\alpha$ did not have any effect $(300+\mathrm{T})$, whereas $400 \mathrm{nM} 5 \mathrm{a}$ and $20 \mathrm{ng} / \mathrm{ml}$ of TNF $\alpha$ had a remarkable effect on cell death $(400+\mathrm{T})$. From these observations, we conclude that 5 a induces a transient change that requires an optimum concentration that can be achieved in $2-3 \mathrm{~h}$ of treatment with $200 \mathrm{nM}$ before adding TNF $\alpha$ or by adding $400 \mathrm{nM} \mathrm{5a}$, and $20 \mathrm{ng} \mathrm{TNF} \alpha$ simultaneously for sensitizing cells to TNF $\alpha$-induced apoptosis.

\section{Compound 5a, a unique MMP-2/MMP-9 inhibitor that enhances cytokine-induced apoptosis}

We screened several other MMPIs (Calbiochem-Novabiochem Corp.,. San Diego, CA, USA) for synergistic interaction with TNF $\alpha$ at $100 \mathrm{nM}$, which was far above their $\mathrm{IC}_{50}$ or their $K_{i}$ values, to test whether they could also sensitize breast cancer
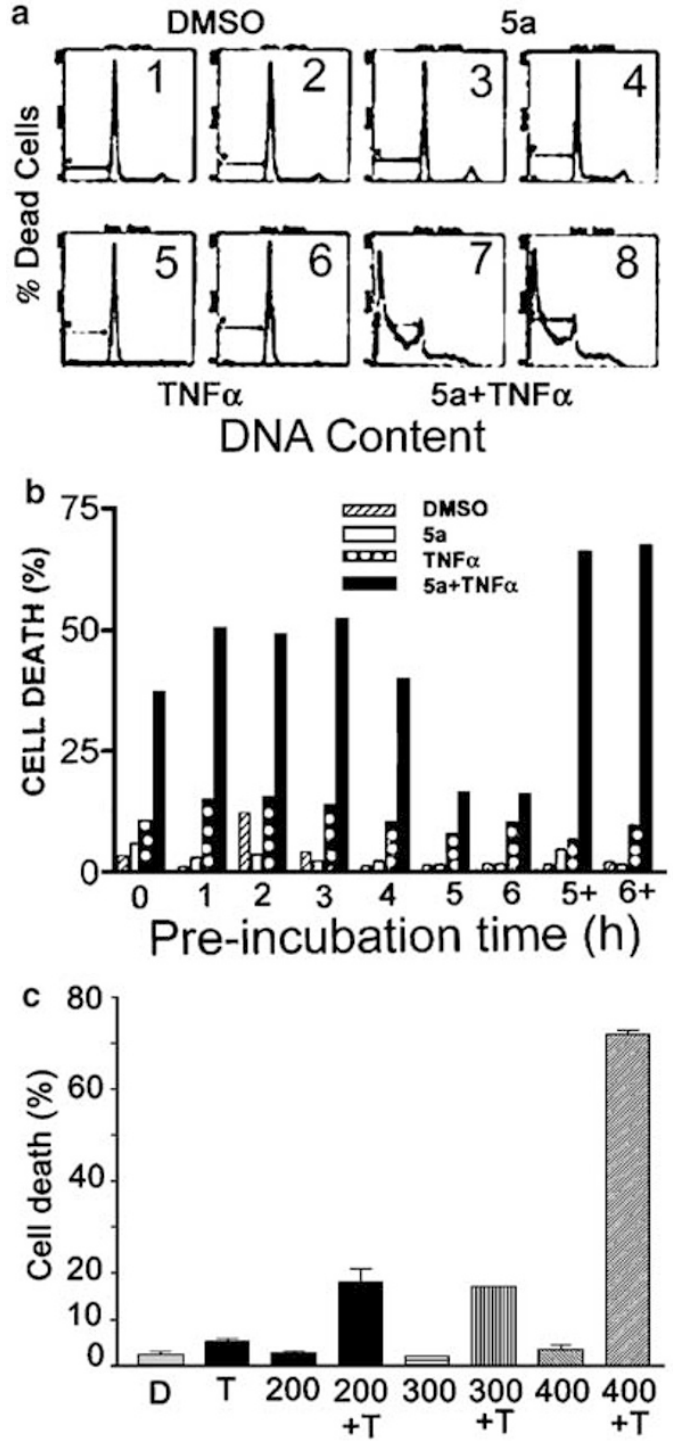

Figure 1 Compound 5 a interacts synergistically with TNF $\alpha$ to enhance apoptosis in cancer cells. (a) FACS analyses of DNA fragmentation of 9D3S breast cancer cells treated with $0.2 \%$ DMSO (panels 1and 2), $200 \mathrm{nM} 5 \mathrm{a}$ (panels 3 and 4), $20 \mathrm{ng} / \mathrm{ml} \mathrm{TNF} \alpha$ (panels 5 and 6 ), and $200 \mathrm{nM} 5 \mathrm{a}$ for $3 \mathrm{~h}$ followed by $20 \mathrm{ng} / \mathrm{ml}$ of TNF $\alpha$ (panels 7 and 8). (b). FACS analyses of 9D3S cells treated with $200 \mathrm{nM} 5 \mathrm{a}$ for various times followed by $20 \mathrm{ng} / \mathrm{ml}$ of TNF $\alpha$ (columns $0-6$ ). Some cells were treated for 5 or $6 \mathrm{~h}$ with $200 \mathrm{nM} 5 \mathrm{a}$ followed by an additional $200 \mathrm{nM} 5 \mathrm{a}$ and then $20 \mathrm{ng} / \mathrm{TNF} \alpha 1 \mathrm{~h}$ later (columns $5+$ and $6+$ ). This is a representative experiment of three performed. (c) FACS analysis of 9D3S cells treated with $0.2 \%$ DMSO, $20 \mathrm{ng} / \mathrm{ml} \mathrm{TNF} \alpha$, and various concentrations of $5 \mathrm{a}(200,300$ and $400 \mathrm{nM}$ ) alone (D, T, 200, 300 and 400), or with $5 \mathrm{a}$ plus $20 \mathrm{ng} / \mathrm{ml} \mathrm{TNF} \alpha(200+\mathrm{T}$, $300+\mathrm{T}$, and $400+\mathrm{T}$ )

cells to TNF $\alpha$-induced apoptosis. They included MMP-2/ MMP-9 inhibitor II ( $\mathrm{IC}_{50} 17$ and $30 \mathrm{nM}$, respectively), MMP-8 inhibitor I $\left(\mathrm{IC}_{50}=4 \mathrm{nM}\right)$, and MMP-9/MMP-13 inhibitor I $\left(\mathrm{IC}_{50}=900 \mathrm{pM}\right)$ and $\mathrm{GM} 8914$, a broad-based MMP inhibitor (MMP-1: $K_{i}=0.2 \mathrm{nM}$; MMP-2: $K_{i}=500 \mathrm{nM}$; MMP-3: $K_{i}=20 \mathrm{nM}$, MMP-8 and MMP-9: $\left.K_{i}=100 \mathrm{nM}\right)$. They were all tested at $100 \mathrm{nM}$. FACS analyses presented in Figure $2 \mathrm{a}$ showed that none of the other MMP inhibitors synergized with TNF $\alpha$ to enhance apoptosis. 


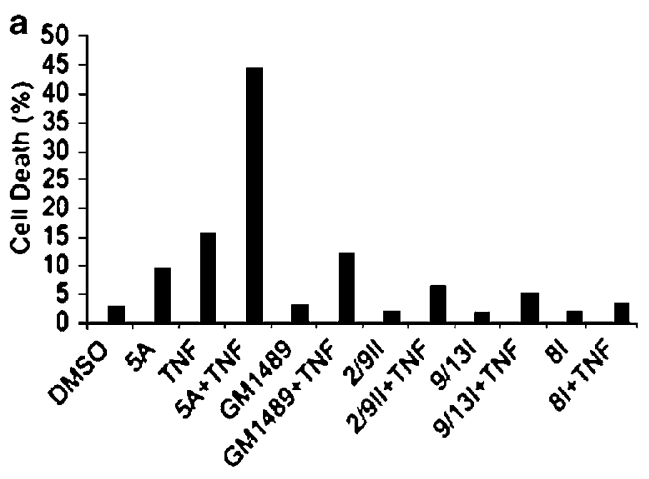

b

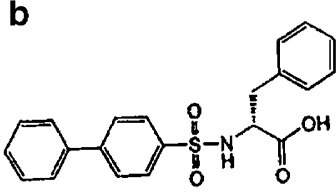

MMP-2/MMP-9 inhibitor I (5a)

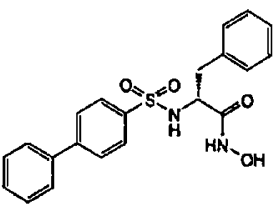

MMP-2/MMP-9 inhibitor II

Figure 2 Compound $5 \mathrm{a}$ is the only tested MMP inhibitor that synergized with $\mathrm{TNF} \alpha$ to enhance apoptosis. All the inhibitors used here were obtained from Calbiochem-Novabiochem Corp., San Diego, CA, USA (a) FACS analysis of 9D3S cells treated with DMSO, $5 \mathrm{a}, \mathrm{TNF} \alpha$, the general MMP inhibitor (GM1489), inhibitors of MMP-2/MMP-9 II (2/9II), MMP-9/MMP-13 (9/13I), and MMP-8 (8I) alone or in combination with TNF $\alpha$. This is a representative experiment of three performed. (b) Chemical structures of two closely related MMP inhibitors: MMP-2/ MMP-9 I (5a) and MMP-2/MMP-9 inhibitor II

The uniqueness and specificity of compound 5 a was further demonstrated by studying another structurally related MMP2/MMP-9 antagonist in more detail. Although MMP-2/MMP-9 inhibitor II is structurally very similar to $5 a$ (Figure $2 b$ ), it did not synergize with TNF $\alpha$ (Figure $2 a$, eighth column from the left) to enhance apoptosis compared to $5 \mathrm{a}$ plus TNF $\alpha$ (Figure 2a, fourth column from the left). This was validated for different concentrations ranging from 100 to $800 \mathrm{nM}$ (data not shown). The highest concentration was about 30-50-fold higher than its $\mathrm{IC}_{50}$ of 17 and $30 \mathrm{nM}$, respectively. These results show that the proapoptotic function of $5 \mathrm{a}$ is not a general property of MMP inhibitors and it is not because of their ability to chelate zinc.

\section{Compound 5a synergizes only with ligands of the TNF receptor superfamily}

Since many agents induce apoptosis, it was necessary to determine whether other apoptotic factors synergize with compound $5 \mathrm{a}$ to enhance apoptosis. This question was relevant to the investigation of the mechanism by which $5 \mathrm{a}$ enhances apoptosis. To that end, various apoptotic agents [UV light, ${ }^{33}$ thapsigargin, ${ }^{34}$ staurosporin, ${ }^{35}$ paclitaxel, ${ }^{36}$ a Fascrosslinking antibody $(\mathrm{CH} 11),{ }^{37}$ and TRAIL $^{38}$ ] were examined. We found that in addition to TNF $\alpha$, anti-Fas (data not shown), and TRAIL interacted synergistically with compound $5 a$ to induce apoptosis. As shown in Figure 3, DMSO, 5a, and $\mathrm{TNF} \alpha$ alone did not significantly induce cell death. However, in

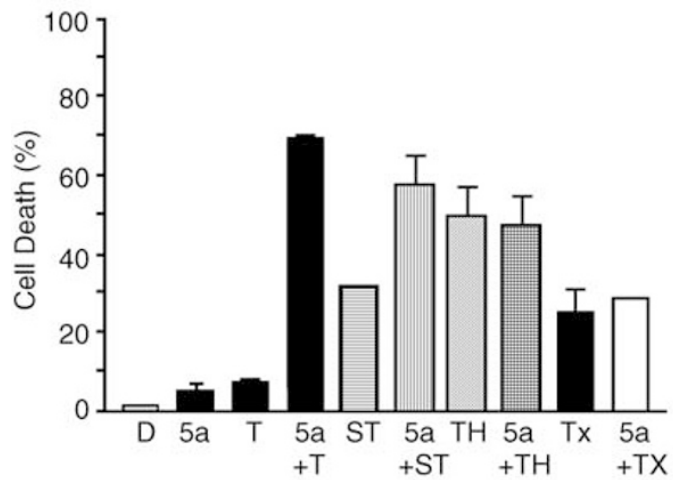

Figure 3 Compound 5a interacts synergistically only with ligands of the TNF receptor superfamily. FACS analysis of 9D3S cells treated with DMSO (D), 5a and TNF $\alpha(T)$; staurosporin (ST), thapsigargin (TH), or paclitaxel (TX) alone or with $5 \mathrm{a}$ in combination with TNF $\alpha$, staurosporin, thapsigargin, or paclitaxel (columns $5 \mathrm{a}+\mathrm{T}, 5 \mathrm{a}+\mathrm{ST}, 5 \mathrm{a}+\mathrm{TH}$, and $5 \mathrm{a}+\mathrm{TX}$ ).

combination, $5 \mathrm{a}+\mathrm{TNF} \alpha$ enhanced apoptosis by about sevenfold (Figure 3, fourth column from the left). In contrast, $200 \mathrm{~J} /$ $\mathrm{cm}^{2}$ of UV light (data not shown), $20 \mathrm{nM}$ staurosporin (ST), $100 \mathrm{nM}$ paclitaxel (TX), and $20 \mathrm{nM}$ thapsigargin (TH) all induced cell death. However, while $5 \mathrm{a}$ had an additive effect with staurosporin, it did not synergize with any of them to enhance apoptosis (Figure 3,5a+ST, $5 a+T H$, and $5 a+T X$ ). From these observations, we conclude that only $T N F \alpha$, TRAIL, and the Fas-cross-linking antibody, all ligands of the TNF receptor superfamily, synergized with 5 a to enhance apoptosis.

\section{Synergy is cell-type specific}

We next determined whether the synergy between $5 \mathrm{a}$ and TNF $\alpha$ was unique to the 9D3S breast cancer cell line. To that end, we tested several other cell lines, including a nontumorigenic transformed breast epithelial cell line (HBL100) ${ }^{39}$ and the aggressively metastatic MDA-MB- $231^{40}$ breast cancer cell line. We also tested the poorly metastatic melanoma cell line $\mathrm{A} 375 \mathrm{P}$ and its metastatic variant melanoma cell line A375SM, ${ }^{41}$ and three osteosarcoma cell lines (MG63, SOAS-2, and TA29), a lymphoblastic leukemia (Z119), and four acute mylogenous leukemia cell lines (AML-2, AML-3, KBM5, and KBM7). FACS analyses revealed that the nontumorigenic transformed normal breast epithelial cell line HBL100 was not sensitive to DMSO, 5a, or TNF $\alpha$ alone or to the combination treatment of 5 a plus TNF $\alpha$ (Figure $4 \mathrm{a}$, panels 1-4). 9D3S cells were sensitive to all three ligands (anti-Fas, TNF $\alpha$, and TRAIL). MDA-MB-231 and the melanoma cell lines (A375P, A375SM) were resistant to TNF $\alpha$ (data not shown). Analysis of cell viability determined by the Trypan blue dyeexclusion method showed that MDA-MB-231 cells were not sensitive to DMSO, 5a, or TRAIL alone (Figure $4 b$, columns D, $5 \mathrm{a}$, and TR), but they were sensitive to combination treatment with $5 a$ and TRAIL (Figure 4b, column 5a+TR). FACS analysis of the melanoma cell lines also showed that they were sensitive to combination treatment of $5 a$ and TRAIL (data not shown). All the leukemia cells were resistant to TNF $\alpha$ (data not shown). However, two of the acute myelogenous leukemia 


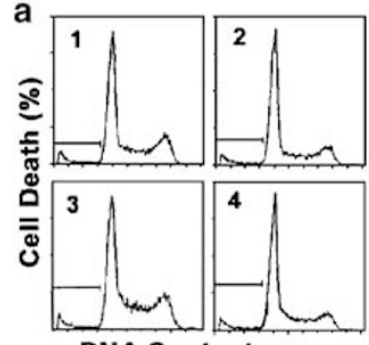

b

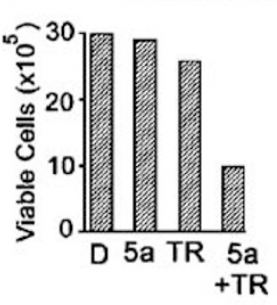

DNA Content
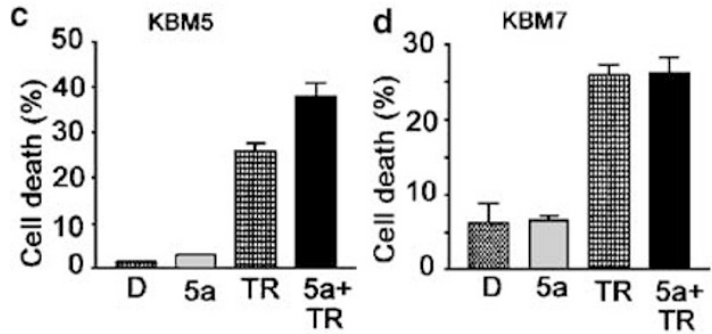

Figure 4 Synergy between 5a and TRAIL to enhance apoptosis is cell-type specific. These are representative experiments done in duplicate several times. (a) Representative FACS analyses of HLB100-transformed normal breast epithelial cells treated with $0.2 \%$ DMSO, 5 a or TRAIL alone (panels $1-3$, respectively) or $5 \mathrm{a}$ in combination with TRAIL (panel 4). (b) Viable cells were determined by the Trypan blue dye exclusion method after MDA-MB-231 breast cancer cells were treated with $0.2 \%$ DMSO (D), $5 \mathrm{a}$, or TRAIL (TR) alone, or $5 \mathrm{a}$ in combination with TRAIL (5a+TR). (c) FACS analysis of KBM5 leukemia cells treated with $0.2 \%$ DMSO (D), 5a and TRAIL (TR) alone, or $5 \mathrm{a}$ in combination with TRAIL (5a+TR). (d) Similar analyses were performed with the KBM7 leukemia cells

cell lines (KBM5 and KBM7) were sensitive to TRAIL and the killing was somewhat enhanced by $5 \mathrm{a}$ in KBM5 but not in KBM7 cells (Figure 4c and d). All three osteosarcoma cell lines were resistant to TNF $\alpha$ and TRAIL alone or in combination with $5 \mathrm{a}$ (data not shown). Thus, 5a enhanced apoptosis in a cell-type specific manner. Therefore, while cell sensitivity to apoptosis induced by certain apoptotic agents was required, it was not sufficient for such agents to interact synergistically with 5 a to enhance apoptosis. Table 1 shows a list of cells used and the results of various treatments.

\section{The effect of compound $5 \mathrm{a}$ on protein synthesis}

In an effort to determine the mechanism by which compound 5 a potentiates apoptosis, we next examined the possibility that 5 a might, like cyclohexamide, ${ }^{42}$ enhance apoptosis by inhibiting protein synthesis. We measured the total protein yield in untreated and treated cells by the Bradford method. As shown in Figure $5 \mathrm{a}$, cells treated with DMSO (column 2), $5 \mathrm{a}$ (column 3) and TNF $\alpha$ (column 4) alone, or 5 a plus $\mathrm{TNF} \alpha$ (column 5) all had about a 15-20\% reduction in total proteins as compared to the untreated control (column 1). We next measured TCA-precipitable L-[ ${ }^{35}$ S]methionine incorporation following different treatments to determine if $5 \mathrm{a}$ inhibited global de novo protein synthesis. As shown in Figure $5 \mathrm{~b}$, de novo synthesized proteins calculated per unit of protein were reduced by about $40 \%$ cells treated with DMSO, $5 a$, or TNF $\alpha$ alone (columns 2-4, respectively) compared to that in untreated control cells (column 1 ) and there was no significant difference among the different treatments. Lastly, we ana-
Table 1 Synergistic effect of $5 a$ on ligand-induced apoptosis in different cell lines

\begin{tabular}{llll}
\hline Cell Lines & $\mathbf{5 a + T N F} \boldsymbol{\alpha}$ & $\mathbf{5 a + T R A I L}$ & $\begin{array}{l}\mathbf{5 a + A n t i - f a s} \\
(\mathbf{C H 1 1 )}\end{array}$ \\
\hline 1. HLB100 & No & No & ND \\
2. 9D3S & Yes & Yes & Ye \\
3. MDA-MB-231 & No & Yes & ND \\
4. A375P & No & Yes & ND \\
5. A375SM & No & Yes & ND \\
6. AML2 & No & No & ND \\
7. KBM5 & No & Additive & ND \\
8. KBM7 & No & No & ND \\
9. MG63 & No & No & ND \\
10. SAOS-2 & No & No & ND \\
11. TA29 & No & No & ND
\end{tabular}

a
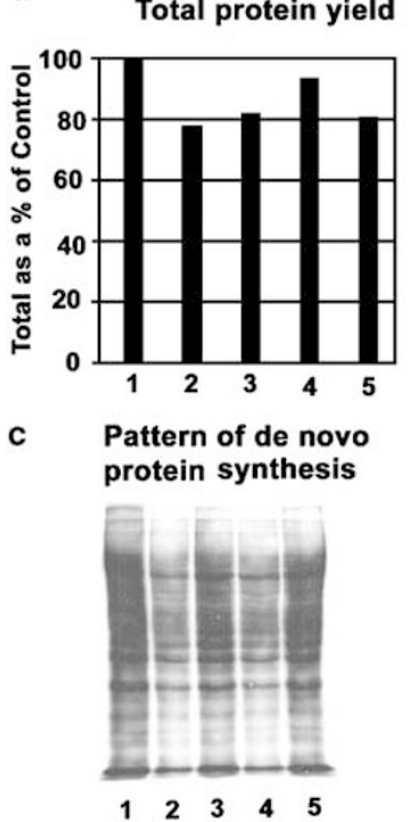

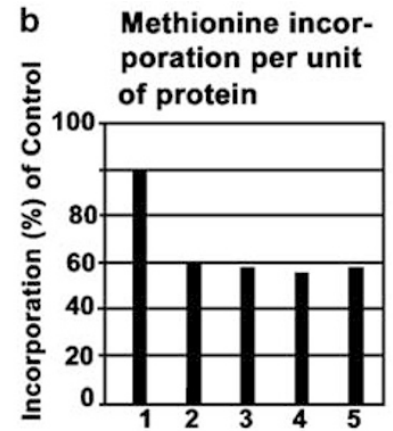

d Western Blot

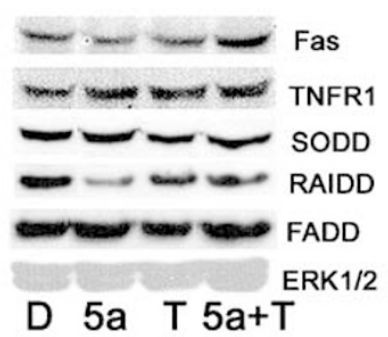

Figure 5 Compound 5 a does not affect protein synthesis. These experiments were done twice and shown here are representative results. (a) Total protein yield (measured by the Bradford method) of extracts of cells that were untreated (1), treated with DMSO, $5 \mathrm{a}$, or TNF $\alpha$ alone or a combination of $5 \mathrm{a}$ and TNF $\alpha$ (columns $1-5$, respectively). (b) TCA-precipitable L- $\left[{ }^{35}\right.$ S]methionine incorporation per unit protein in the same samples described in (a). (c) Autoradiographic analyses of the pattern of de novo synthesized proteins of the same samples described in (a). (d) Western blot analysis of proteins that constitute the deathinducing signaling complex (DISC), including Fas, TNFR1, SODD RAIDD, and FADD, after treatment with DMSO (lane D), $5 a$ (lane $5 \mathrm{a}$ ), or TNF $\alpha$ (lane T) alone or $5 \mathrm{a}$ in combination with TNF $\alpha$ (lane $5 \mathrm{a}+\mathrm{T}$ ). ERK $1 / 2$ was included to show equal loading

lyzed the pattern of newly synthesized proteins by autoradiography following sodium dodecyl sulfate polyacrylamide gel $(10 \%)$ electrophoresis (SDS-PAGE) to determine whether expression of some proteins were down- or upregulated. There was no detectable differential effect on de novo protein synthesis during the $2-\mathrm{h}$ labeling period (Figure $5 \mathrm{c}$ ). Collectively, these data indicate that 5 a does not act through the inhibition of de novo protein synthesis. 
We next analyzed proteins extracted from cells treated with DMSO, $5 \mathrm{a}$ or TNF $\alpha$ alone, or with $5 \mathrm{a}$ in combination with TNF $\alpha$ for the expression of pro- and antiapoptotic proteins by Western blotting. The same membrane was stripped several times and reprobed with different antibodies. We did not detect any significant difference in the expression levels of the antiapoptotic factors including the silencer of the death domain (SODD) ${ }^{43,44}$ (Figure 5d) and Flice-inhibiting protein (FLIP) $^{45}$ (data not shown) or the pro-apoptotic factors Fas, ${ }^{46}$ TNFR1, ${ }^{47}$ FADD $^{48}$ RAIDD $^{49}$ (Figure $5 \mathrm{a}$ ) and caspase $8^{50}$ (data not shown). ERK1/2 was included to assure equal loading (Figure $5 \mathrm{~d}$ ). These observations indicate that $5 \mathrm{a}$ does not target the expression of these proteins.

We next performed detailed time course experiments in which we analyzed TNFR1 expression at 0, 0.5, 1, 2, 3, and $6 \mathrm{~h}$ after initiating treatment with DMSO, 5a, or TNF $\alpha$ alone, or $5 a$ followed by TNF $\alpha$. Cytosolic and membrane-associated proteins were analyzed by Western blotting for TNFR1. There was no significant difference in the level of TNFR1 expression during this period (Figure 6) despite the fact that the highest level of synergy between $5 a$ and TNF $\alpha$ occurred when TNF $\alpha$ was added 2-3 $\mathrm{h}$ after pre-incubation with $5 \mathrm{a}$ (see Figure $1 \mathrm{~b}$ ).

To distinguish between membrane-bound and cytosolic TNFR1, we used the indirect biotinylated-avidin immunofluorescent method as described in Materials and Methods. Results of FACS analysis (data not shown) show that 5a did not affect the level of membrane-bound TNFR1. Additionally, we searched for receptor shedding by Western blotting, for truncated forms of TNFR1 in cell culture medium that had been concentrated by a factor of 100 . Although we detected intact TNFR1 in the medium, we did not find any evidence that TNFR1 was shed from the cell membrane into the medium, which would be characterized by truncated receptors (data not shown).

Collectively, these observations show that the mechanism by which $5 \mathrm{a}$ enhances ligand-induced apoptosis is not mediated by changes in protein synthesis or inhibition of shedding of membrane-bound members of the TNF receptor superfamily.

\section{TRAIL decoy receptor 1 (DcR1) abrogates synergy between $5 \mathrm{a}$ and TRAIL}

To investigate the role of the receptor-ligand interaction in synergy between $5 a$ and $\operatorname{TNF} \alpha$, we pretreated cells with the

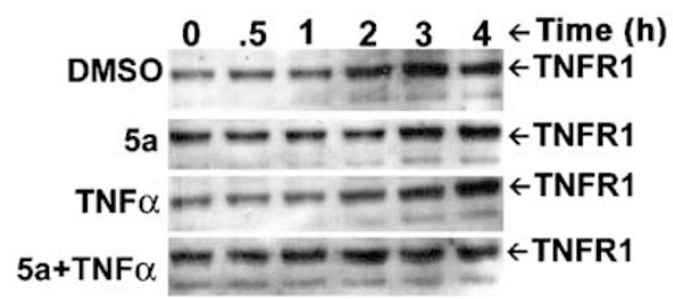

Figure 6 Time course of TNFR1 expression. Results of Western blot analysis of TNFR1 expression in 9D3S breast cancer cells. Cells from different treatment groups were prepared at different time points as indicated in the figure. No changes were observed in TNFR1 expression between the different treatment groups. This experiment was done twice and a representative result is shown here

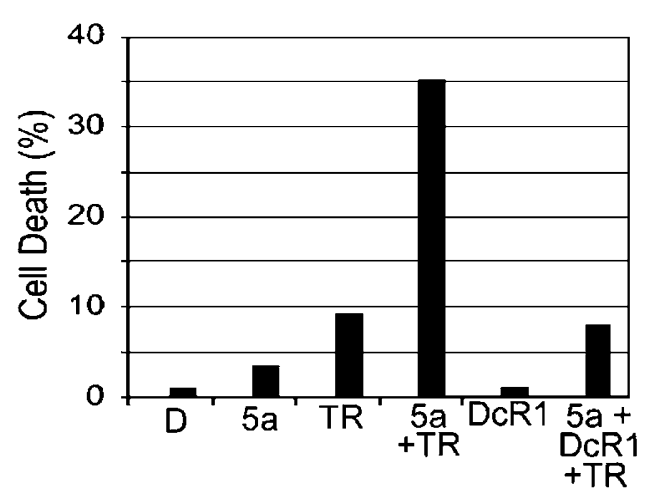

Figure 7 TRAIL decoy receptor 1 abrogates synergy between $5 \mathrm{a}$ and TNF $\alpha$ to enhance apoptosis. FACS analyses of cells treated with DMSO (D), 5a, TRAIL (TR) and TRAIL decoy receptor 1 (DcR1) alone, 5a in combination with TRAIL $(5 a+T R)$, or $5 a$ followed by DcR1 and TRAIL $(5 a+D c R 1+T R)$. This is a representative experiment of three performed

TRAIL DcR1 $1^{51,52}$ and then treated them with TRAIL. This receptor binds the ligand, but because it lacks the intracellular domain, it cannot transduce the death signal into the cell. As shown in Figure 7, DMSO (D), 5a, TRAIL (TR), and DcR1 alone had no significant effect on cell death. However, treatment with a combination of $5 a$ and TRAIL $(5 a+T R)$ enhanced apoptosis. The DcR1 effectively blocked the synergistic interaction between TRAIL and $5 \mathrm{a}$, indicating that ligand-receptor interaction is essential for initiating the deathsignaling cascade that leads to the enhancement of apoptosis.

\section{Caspase activation}

We next determined whether $5 \mathrm{a}$ affects death signaling downstream of the receptor-ligand interaction. To that end, we examined cell extracts for the activity of caspase 8, which initiates the caspase death-signaling cascade. Firstly, we observed that the general caspase anagonist z-Val-AlaAsp(OMe)-fluoromethyl ketone (zVADfmk) inhibited 5a-enhanced apoptosis (data not shown), as did the caspase 8 inhibitor, z-Ile-Glu(OMe)-Thr-Asp(Ome)-fluoromethyl ketone (zIETDfmk) (Figure 8a, column I+5a+T). Secondly, using a colorimetric assay for activated caspase 8 , we showed that DMSO, 5a, and TNF $\alpha$ alone had no significant effect on caspase 8 activity at 12 or $20 \mathrm{~h}$ (Figure $8 \mathrm{~b}$ ), but combination treatment elicited a substantially high level of caspase 8 activity (Figure $8 \mathrm{~b}$ ). These findings constitute the first evidence that the most-upstream change in the caspase cascade that occurs in 5 a-enhanced apoptotic cells is the activation of caspase 8 .

\section{Mitochondrial transmembrane potential}

Some apoptotic agents alter the mitochondrial transmembrane potential (MTP), which leads to the release of apoptosis-related factors, including cytochrome $c^{53}$ and Smac. ${ }^{54,55}$ We investigated whether $5 \mathrm{a}$ alone or in combination with TNF $\alpha$ alters the MTP. Figure 9 shows that DMSO (D), $5 \mathrm{a}$, and $\operatorname{TNF} \alpha(\mathrm{T})$ alone did not alter MTP, but TNF $\alpha-5 \mathrm{a}$ combination reduced the MTP by about $35 \%$ (Figure 9, 
a

Inhibition of apoptosis by caspase 8 antagonist
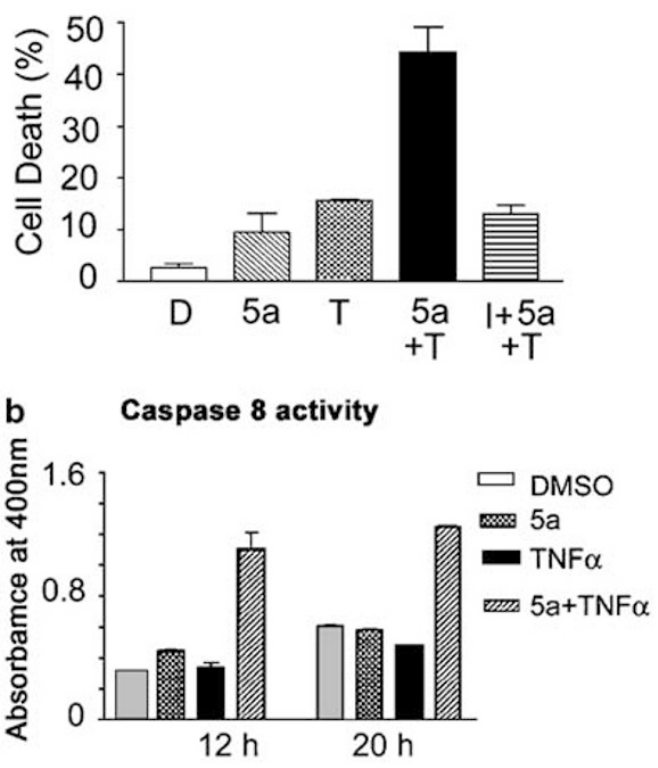

Figure 8 Compound $5 a$ interacts synergistically with TNF $\alpha$ to activate caspase 8. (a) FACS analyses of 9D3S cells treated with DMSO (D), 5a and TNF $\alpha$ (T) alone, $5 \mathrm{a}$ in combination with TNF $\alpha(5 \mathrm{a}+\mathrm{T})$, or caspase 8-preferred inhibitor followed by $5 \mathrm{a}$ and $\mathrm{TNF} \alpha(1+5 \mathrm{a}+\mathrm{T})$. (b). Caspase 8 activity measured by the colorimetric method in cells treated for 12 or $20 \mathrm{~h}$ as described in $(\mathbf{A})$

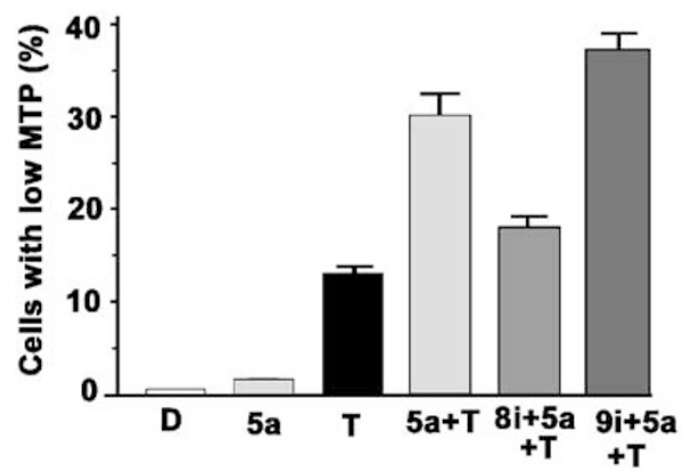

Figure 9 Compound $5 a$ interacts synergistically to reduce MTP. Changes in the MTP were measured by the reduction in the amount of $\mathrm{DiCO}_{6}$ loaded into cells following various treatments. MTP is shown in cells treated with DMSO (D) $5 \mathrm{a}$ and TNF $\alpha(\mathrm{T})$ alone, and those treated with a combination of $5 \mathrm{a}$ and TNF $\alpha$ in the absence $(5 a+T)$ or in the presence of caspase 8 inhibitor $(8 i+5 a+T)$ and caspase 9 inhibitor $(9 \mathrm{i}+5 \mathrm{a}+\mathrm{T})$

column $5 a+T)$. This reduction in the MTP was inhibited if the cells were preincubated with an antagonist of caspase 8 (zIETDfmk) $(8 \mathrm{i}+5 \mathrm{a}+\mathrm{T})$ but not with an inhibitor of caspase 9 , zLeu-Glu(OMe)-His-Asp(OMe)-fluoromethyl ketone (zLEHDfmk) $(9 i+5 a+T)$. These results suggest that the signal that altered the MTP came from activated caspase 8 and not from within the mitochondrion. The failure of the caspase 9 inhibitor to abrogate the reduction in MTP induced by combination treatment was consistent with the conclusion that the signal for synergy between $5 \mathrm{a}$ and TNF $\alpha$ to enhance apoptosis was initiated upstream of the mitochondrion.

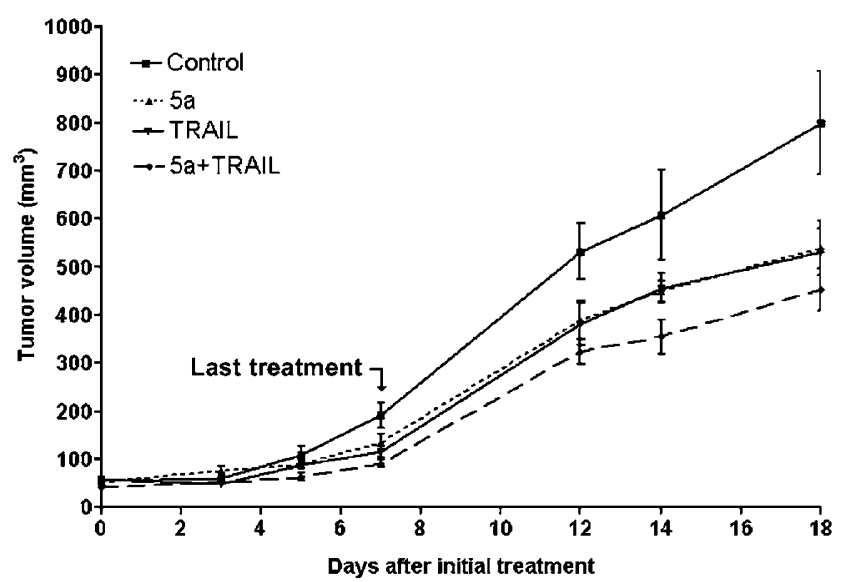

Figure 10 Effect of $5 \mathrm{a}$ and TRAIL treatment on tumor growth of human melanoma cells. Athymic nude mice (6-8 weeks old) were injected subcutaneously with $5 \times 10^{5}$ A375SM melanoma cells in $200 \mu$ PBS. When tumors became palpable after a week, the mice were divided into four treatment groups containing 10 animals each. The treatment groups were: untreated control, 5a alone, TRAIL alone, and 5a+TRAIL (i.p. for 7 days). Tumor volumes were measured twice a week for 18 days. Each plot is the average of tumor volumes of 10 animals per group. Note that treatment with 5a+TRAlL inhibited the growth of A375SM melanoma cells by two-fold as compared to control groups $(P<0.05)$

\section{In vivo study}

To determine if the proapoptotic effect of 5 a observed in vitro also occurs in vivo, we next monitored the effect of individual and combination treatment on the growth of A375SM melanoma cells implanted subcutaneously into nude mice. Tumor volume in each animal was measured twice a week. Figure 10 shows that by the end of 18 days, the tumors in the control group reached the size of $800 \mathrm{~mm}^{3}$. While treatment with $5 \mathrm{a}$ or TRAIL alone reduced the growth of A375SM cells by about the same amount, combination treatment with $5 a+$ TRAIL was the most effective and resulted in tumor size of only $\sim 450 \mathrm{~mm}^{3}$. The reduction in tumor growth by combination treatment compared to 5 a or TRAIL alone was significantly different $(P<0.05)$. The data also show that once the treatment was stopped, the tumor resumed growth, suggesting that it may require continuous or a more extended course of combination treatment ( $>7$ days) to completely arrest tumor growth.

Tumor sections were also examined for apoptosis by the TUNEL method and for microvessel formation by immunohistochemical method using a CD31-specific antibody. Shown in Figure 11 are representative pictures of TUNEL staining (second column) and CD31 staining (third column) and the composite picture of TUNEL staining superimposed on CD31 staining (first column). Untreated tumors had no apoptotic (TUNEL positive) cells, but they did have abundant microvessels (Figure 11a). Cells treated with $5 \mathrm{a}$ alone had some apoptotic cells but a reduced number of blood vessels (Figure 11b). In contrast, tumors treated with 5 a plus TRAIL had a higher number of apoptotic cells, concomitant with a reduced number of blood vessels (Figure 11c). These results suggest that $5 \mathrm{a}$ in combination with TRAIL inhibits tumor growth by enhancing apoptosis and by inhibiting angiogenesis in vivo. 


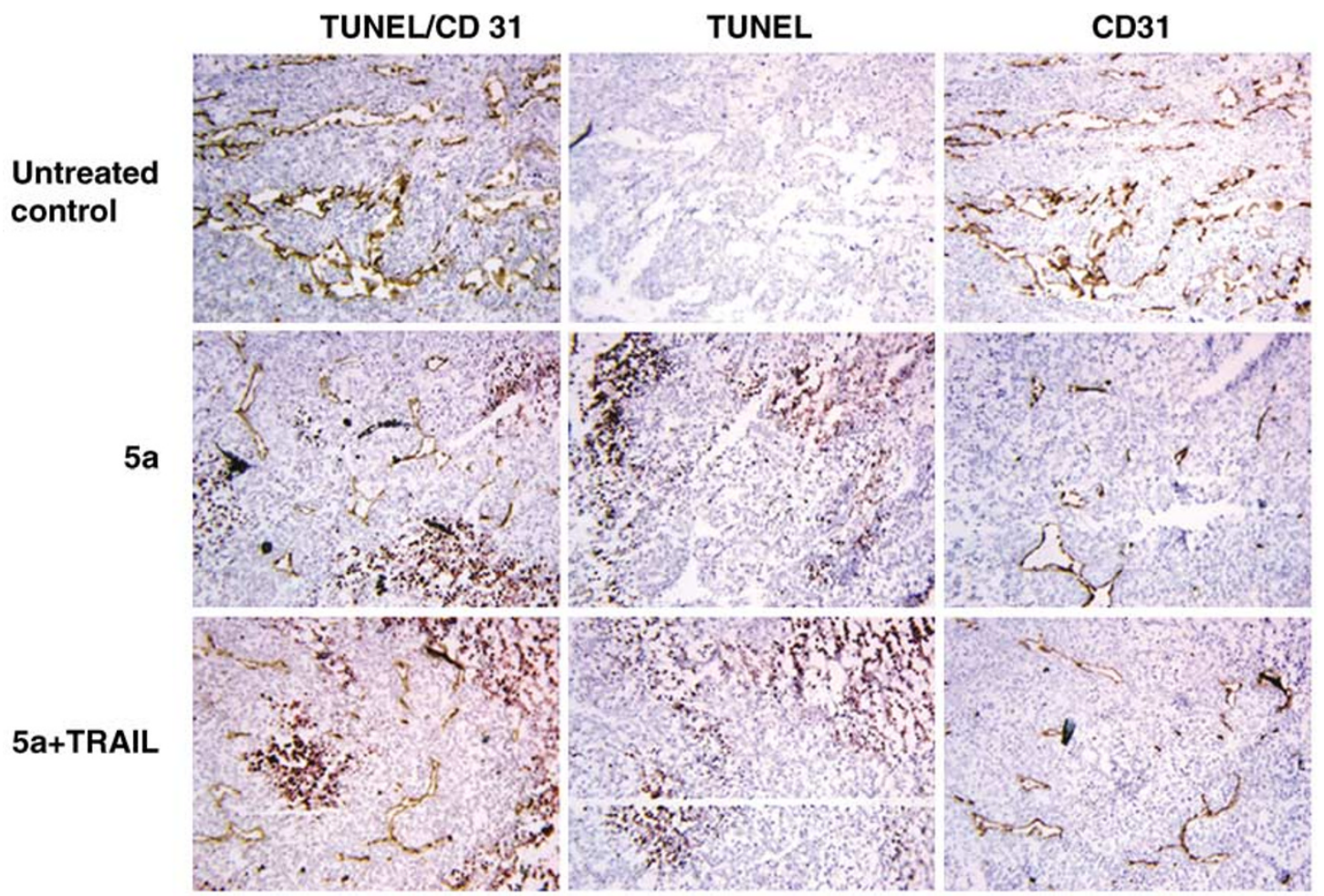

Figure 11 Apoptosis and tumor microvessels in the same subcutaneous melanoma described above (Figure 10). After 7 days of daily treatment, mice were kept for another 11 days for further observations. Tumor sections were stained for apoptosis by TUNEL and for microvessels by CD31-specific antibody. Shown are pictures of TUNEL staining alone (second column), CD31 staining alone (third column), and superimposed pictures of TUNEL and CD31 (first column). Untreated control tumor (top row), 5a-treated tumor (middle row) and 5a plus TRAlL-treated tumor (bottom row) A375SM melanoma cells. These are representative fields

\section{Discussion}

In this study, we have demonstrated that an MMP-2/MMP-9 inhibitor, 5a, selectively augments apoptosis induced by ligands of the TNF receptor superfamily, specifically $T N F \alpha$, TRAIL, and the crosslinking anti-Fas antibody, in a cell-type specific manner. Several factors could account for the unique characteristics of $5 \mathrm{a}$. For example, the finding that $5 \mathrm{a}$ is the only MMPI that interacted synergistically with ligands of the TNF receptor superfamily to induce apoptosis might be because of its chemical structure. As shown in Figure $2 b$, the most structurally similar inhibitors (5a and MMP-2/MMP-9 inhibitor II) differ at least in three moieties, which could account for the differences in their behavior. The inhibitors may also differ in their ability to be absorbed onto or into cells, and once absorbed, the inhibitors may differ in their stability. Some of them may be rapidly inactivated by secondary modifications such as phosphorylation, methylation, or sulfonation. Furthermore, the inhibitors could be confined to an inaccessible cellular compartment or pumped out such that the intracellular concentration never reaches the critical level required for synergy. Since the mechanism of MMP inhibition involves chelation of zinc, yet synergy was selective, it is conceivable that the uniqueness of 5 a to synergize with ligands of the TNF receptor superfamily to enhance apoptosis derives from its ability to utilize a yet unknown additional factor.

Cell-type specificity of the observed synergy could be explained in several ways. Different cell types express different amounts of the TNF receptor superfamily, ${ }^{56}$ proapoptotic factors, including caspases ${ }^{57,58}$ and Smac, ${ }^{54,55}$ or antiapoptotic factors such as SODD, ${ }^{43,44}$ FLIP, ${ }^{45}$ and IAP. ${ }^{59}$ Cells that express more receptors and proapoptotic factors or less antiapoptotic factors would be predicted to facilitate synergy between $5 \mathrm{a}$ and ligands of the TNF receptor superfamily.

At present, there is no information on the targets of $5 \mathrm{a}$ apart from MMP-2/MMP-9 described in the original studies ${ }^{30,31}$. It is not yet known whether 5 a targets exclusively MMP-2/MMP-9 or other proteases such as TACE and other members of the ADAM family. Studies are underway using radiolabeled $5 a$ to determine whether 5 a binds to a specific molecule or a class of molecules, including proteins and nucleic acids.

Our observations are significant because of the growing interest in the potential for developing MMPIs as a new class of cancer drugs. ${ }^{60}$ Many MMPIs have been reported to be active against tumor growth, invasion, and metastasis. ${ }^{61,62}$ However, since these MMPIs are structurally different from $5 \mathrm{a}$, and since some of them are effective against cells that are refractive to $5 a-e n h a n c e d$ apoptosis, ${ }^{62}$ it is likely that their mechanisms of action are different. Although it is assumed that the antineoplastic activity of MMPIs is because of their inhibition of MMPs, through their zinc-chelating activity, our findings do not support this notion. For example, not all MMPIs, including those that are more efficient than $5 \mathrm{a}$ in chelating zinc, do not all enhance TNF $\alpha$-induced apotosis. Additionally, the cells in which synergy between $5 \mathrm{a}$ and ligands of the TNF receptor superfamily have been observed 
express variable levels of MMP-2/MMP-9 enzymes. Furthermore, despite the fact that some studies have reported receptor shedding induced by $\mathrm{MMPs}^{26}$ suggesting that MMPIs would act to stabilize receptors, we did not find any evidence to support such a notion.

It should be pointed out that other studies have also shown that MMPIs such as AG3340 work against tumors by inhibiting angiogenesis ${ }^{63}$ whereas batimistat $(B B-94)^{64}$ was reported to act by perturbing the cell cycle. However, in both cases, the exact mechanism is not yet known. The induction of cell cycle arrest and apoptosis by MMPIs was also reported in kidney inflammatory cells. ${ }^{65}$ Whether or not the same mechanism works in tumor cells is yet to be determined.

Based on our findings, the most likely mechanism of $5 \mathrm{a}$ augmentation of TNF $\alpha$-induced apoptosis is the enhancement of caspase 8 activation. However, the exact mechanism by which 5 a augments the activation of caspase 8 is not yet known. It should be pointed out that in a study of a prostatic carcinoma cell line, LNCaP, it was demonstrated that caspase 8 activation was necessary but not sufficient for TRAILinduced apoptosis. ${ }^{66}$ Collectively, these findings suggest that the proapoptotic activity of $5 \mathrm{a}$ might be unrelated to the inhibition of MMP-2/MMP-9 enzymes.

The synergistic interaction between $5 \mathrm{a}$ and TRAIL in particular has important implications for cancer treatment. Compound $5 \mathrm{a}$ was effective in synergizing with TRAIL in nanomolar concentrations, whereas, $5 a$ by itself at such low concentrations, had no adverse effect on cells. Since $5 a$ appeared to be active only against TRAIL-sensitive cells, its action should be selective for tumor cells because TRAIL does not kill normal cells. ${ }^{67-70}$ This was also evident from our observation that the nontumorigenic transformed normal breast epithelial cell line (HLB100) was not sensitive to combination treatment with $5 \mathrm{a}$ and TRAIL. Indeed, preliminary in vivo study showed that combination treatment of subcutaneously planted melanoma cells with 5 a and TRAIL reduced tumor volumes by at least $50 \%$ compared to that of the untreated control tumors during a week of daily treatment (Figure 10).

In summary, we provide evidence that compound $5 \mathrm{a}$ is an MMP-2/MMP-9 inhibitor that enhances apoptosis induced by ligands of the TNF receptor superfamily, specifically TNF $\alpha$, TRAIL, and the Fas-crosslinking antibody. The synergy was observed only in breast and melanoma cell lines and not in transformed normal breast epithelial cell line, leukemia, or osteosarcoma cell lines, indicating that it is cell-type specific. Our data also indicate that the 5a-enhanced TNF $\alpha$-induced apoptosis is not mediated by changes in protein synthesis, nor does it involve $5 \mathrm{a}$ acting directly on the mitochondrion. Instead, the mechanism requires a ligand-receptor interaction and activation of caspase 8. Furthermore, we showed that combination treatment of subcutaneous melanoma with $5 \mathrm{a}$ and TRAIL inhibited tumor growth and angiogenesis in nude mice. However, the inhibition of tumor growth appears to require continuous treatment. These observations show that 5 a can be a useful tool for investigating the role of ligandreceptor interaction in modulating tumor growth, invasion, and metastasis, and it also offers opportunities for developing novel cancer therapies.

\section{Materials and Methods}

\section{Cell culture}

Cell line 9D3S was derived from the ZR-75-1 as described previously. ${ }^{32}$ HBL100 was obtained from Dr. Michael Tainsky (Wayne State University, Detroit, MI, USA, who obtained it initially from the American Type Culture Collection). The following cell lines were obtained from colleagues at the University of Texas MD Anderson Cancer Center: MDAMB-231 breast cancer cell line (Dr. Janet E Price); MG63, TA29, and SAOS2 osteosarcoma cell lines (Dr. Eugenie Kleinerman); and AML2, AML3, KBM5, KBM7, and Z119 leukemia cell lines (Dr. Srdan Verstovsek).

Breast cancer cells were maintained in 100-mm plastic dishes in RPMI 1640 medium, supplemented with $10 \%$ fetal bovine serum (HyClone, Logan, UT, USA), 100 units of penicillin, $100 \mu \mathrm{g} / \mathrm{ml}$ of streptomycin, and a $1 \times$ solution of sodium pyruvate (GIBCO-BRL Life Technologies, Grand Island, NY, USA) in a humidified incubator with $5 \% \mathrm{CO}_{2}$ atmosphere. Cultures were replenished with fresh medium every 3-4 days and were split 1:4 whenever they reached about $90 \%$ confluence. Adherent cells were harvested by trypsinization in calcium-free phosphate-buffered saline (PBS). Unattached 9D3S cells were harvested by repeatedly pipetting the medium.

\section{Treatment with MMP inhibitors}

Cells were seeded at $2.5 \times 10^{6}$ per $100 \times \mathrm{mm}$ dish in $6 \mathrm{ml}$ of normal medium overnight. They were then treated with $200 \mathrm{nM} 5 \mathrm{a}$ for $3 \mathrm{~h}$ followed by $20 \mathrm{ng} / \mathrm{ml} \mathrm{TNF} \alpha$ and incubated for another $17 \mathrm{~h}$. Samples were analyzed for the effect of treatment by specific assays as described in specific subsections below. For FACS analysis, $2.5 \times 10^{5}$ cells in $3 \mathrm{ml}$ of medium in six-well dishes were used instead. The concentration of other MMPIs were adjusted to at least three-fold their $I_{50}$ or $K_{\mathrm{i}}$ values. All MMPIs were purchased from Calbiochem-Novabiochem Corp., San Diego, CA, USA.

\section{Protein extraction}

Subcellular fractions were prepared according to a modified method of Dignam $^{71}$ in which $2 \mu \mathrm{M}$ instead of $0.2 \mathrm{mM}$. phenylmethylsulfonyl fluoride (PMSF) (Sigma Chemicals, St. Louis, MO, USA) together with other protease inhibitors were used. All extraction buffers contained a cocktail of protease inhibitors including $1 \mu \mathrm{g} / \mathrm{ml}$ of aprotinin, $1 \mu \mathrm{g} / \mathrm{ml}$ of leupeptin, $10 \mu \mathrm{M}$ iodoacetamide, $1 \mu \mathrm{M}$ benzamidine, and $2 \mu \mathrm{M}$ PMSF as previously described. ${ }^{72}$ Briefly, cells were grown to $70-80 \%$ confluence, scraped off the plates, washed once with PBS and once with hypotonic buffer (10 mM HEPES, pH 7.9, $1.5 \mathrm{mM} \mathrm{MgCl}_{2}, 10 \mathrm{mM} \mathrm{KCl}, 2 \mu \mathrm{M}$ PMSF, and $0.5 \mathrm{mM}$ DTT), and chilled in hypotonic buffer in ice for $10 \mathrm{~min}$. Cells were lysed in a 2-ml glass homogenizer with a loose-fitting pestle (type B). Lysates were separated into nuclei (pellet) and other components (supernatant) by centrifugation at $230 \times g$ in a Tommy desktop centrifuge. The nuclear pellet was resuspended in $0.2 \times$ volume of the original cell pellet of $0.02 \mathrm{M} \mathrm{KCl}$ followed by an equal volume of $1.2 \mathrm{M} \mathrm{KCl}$ and extracted by gentle agitation for $30 \mathrm{~min}$ at $4^{\circ} \mathrm{C}$. The supernatant (containing cytoplasmic proteins and membrane fragments) and the nuclear extract were clarified at $20000 \times g$ at $4^{\circ} \mathrm{C}$ for $45 \mathrm{~min}$. The protein concentration of each extract was determined by the Bradford method according to the manufacturer's instructions (BioRad, Hercules, CA, USA). Extracts were divided into $50-\mu$ l aliquots and stored at $-80^{\circ} \mathrm{C}$ until analyzed. 


\section{Western blot analysis}

Total, cytoplasmic, and nuclear cell extracts were analyzed by Western blot as described previously. ${ }^{73}$ Briefly, $10-25 \mu \mathrm{g}$ of each subcellular protein or $75-100 \mu \mathrm{g} / \mathrm{ml}$ of total cellular proteins were resolved by SDSPAGE in a BioRad Mini Protein III gel apparatus, transferred to an Immobilon-P membrane (Millipore Corp., Bedford, MA, USA), and blocked with $3 \%$ nonfat dry milk in Tris-buffered saline consisting of $20 \mathrm{mM}$ Tris base, $137 \mathrm{mM}$ sodium chloride, and 0.05\% Tween 20, pH 7.6 (TBST) for $1 \mathrm{~h}$ at room temperature or overnight at $4{ }^{\circ} \mathrm{C}$. This was followed by incubation with the desired dilution of the primary antibodies in TBST containing $1 \%$ nonfat dry milk for $1 \mathrm{~h}$ at room temperature or overnight at $4^{\circ} \mathrm{C}$. Excess antibody was washed off twice for $15 \mathrm{~min}$ with $20 \mathrm{ml}$ of TBST, and the membrane was incubated with a 1:3000 dilution of horseradish peroxidase-conjugated secondary antibodies for $1 \mathrm{~h}$ at room temperature. Membranes were washed as above. The enhanced chemiluminescence $(E C L)$ reagents that detect bands of reactive proteins were used as described by the manufacturer (Amersham Pharmacia Biotech, Arlington Heights, IL, USA). Chemiluminescent signals were captured on Kodak Bio-MAX MR X-ray films, which were obtained from Sigma (St. Louis, MO, USA).

\section{Flow cytometry}

To detect TNF $\alpha$-induced DNA fragmentation, cells were prepared as described previously. ${ }^{32}$ Briefly, cells were treated with the appropriate agents as described elsewhere in this paper. At least $5 \times 10^{5}$ cells were removed from the plate, pelleted at $900 \times g$ in a swing bucket centrifuge, washed once with PBS, and resuspended in $0.75 \mathrm{ml}$ of a $50 \mu \mathrm{g} / \mathrm{ml}$ solution of propidium iodide, comprising $3 \mathrm{mM}$ sodium citrate and $0.1 \%$ Triton $\mathrm{X}$ 100. Cell suspensions were incubated at $4^{\circ} \mathrm{C}$ for $12 \mathrm{~h}$. They were then analyzed for DNA fragmentation and cell cycle stage by an Epics Profile flow cytometer (Coulter Corp., Miami, FL, USA). The percentage of apoptotic cells was measured by the percentage of subdiploid cells.

\section{Biosynthetic protein labeling}

The question of whether compound 5 a nonspecifically inhibits protein synthesis was addressed by labeling newly synthesized proteins with radioactive methionine.. Briefly, 9D3S cells were seeded in complete RPM1640 medium at $2.5 \times 10^{5}$ per well of a 12 -well plastic plate overnight. The medium was removed by centrifugation, and cells were washed once in $5 \mathrm{ml}$ of PBS and resuspended in labeling medium consisting of DMEM without methionine, supplemented with $5 \%$ dialyzed fetal bovine serum. At time zero, cells were divided into five groups. The first group was left untreated, the second and fourth groups were treated with DMSO, and the third and fifth groups were treated with $200 \mathrm{nM}$ (2R)-2-[(4-biphenylsulfonyl)amino]-3-phenylproprionic acid (compound 5a) (Calbiochem-Novabiochem Corp., San Diego, CA, USA). After $3 \mathrm{~h}$, the fourth and fifth groups were treated with $20 \mathrm{ng} / \mathrm{ml}$ of TNF $\alpha$. An hour later, the medium was supplemented with $10 \mu \mathrm{Ci}$ of L- $\left[{ }^{35} \mathrm{~S}\right]$ methionine per well. Incubation was continued for $2 \mathrm{~h}$. At $6 \mathrm{~h}$, cells were harvested, and the unincorporated radiolabel was removed by centrifugation. Cell pellets were washed once with ice-cold PBS and lysed in $200 \mu$ l of radioimmune precipitation assay (RIPA) buffer (PBS containing $0.03 \mathrm{M}$ sodium citrate and $0.5 \% \mathrm{NP}-40$ ). The protein concentration was determined by the Bradford method. Aliquots of $5 \mu \mathrm{g}$ of protein were precipitated in $500 \mu$ l of ice-cold $20 \%$ trichloroacetic acid (TCA) on ice for $30 \mathrm{~min}$. The precipitate was collected on glass microfiber filters (Whatman International Ltd, Maidstone, England) and washed with $3 \mathrm{ml}$ of
$10 \%$ ice-cold TCA, and the radioactivity was determined in a scintillation counter.

\section{Colorimetric assay for activated caspases}

To detect activated caspase 8 , cells were treated with $0.2 \%$. DMSO, $200 \mathrm{nM} \mathrm{5a}$, and $20 \mathrm{ng} / \mathrm{ml}$ TNF $\alpha$ for the desired time and then processed using activated caspase detection kits according to the manufacturer's instructions (Biosourse International, Camarillo, CA, USA). Briefly, $2.5 \times 10^{6}$ cells were seeded per $100-\mathrm{mm}$ plastic dish overnight. Control cells were pretreated with $0.2 \%$ DMSO, while others were pretreated with $200 \mathrm{nM} 5 \mathrm{a}$ for the desired time and washed once with $5 \mathrm{ml}$ of PBS, and the pellet was resuspended in $50 \mu \mathrm{l}$ of cold lysis buffer. Aliquots of $100 \mu$ l were assayed for caspase 8 using the synthetic substrate Ile-Glu-Thr-Asp-7-amino-4-trifluoromethyl coumarin (IETDAFC), according to the manufacturer's instruction. Caspase activity was measured by determining the absorbance at $400 \mathrm{~nm}$ using Ultrospec 3000pro spectrophotometer (Amershampharmacia Biotech, Cambridge, England).

\section{Time course experiment}

Breast cancer cells (9D3S) were seeded at $3 \times 10^{5}$ per well of a six-well plate in $3 \mathrm{ml}$ of medium and incubated overnight. Cells in 12 wells (26-well plats) were treated with $0.2 \%$ DMSO and an equal number of wells were treated with $200 \mathrm{nM} \mathrm{5a}$. Cells were removed at $0,0.5,1,2$, and $4 \mathrm{~h}$ following treatment, washed once with PBS, and blocked with $3 \% \mathrm{BSA}$ (Pierce, Rockford IL, USA) for $1 \mathrm{~h}$ at $4^{\circ} \mathrm{C}$. This was followed by incubation with a 1:250 dilution of rabbit anti-human TNFR1 for $1 \mathrm{~h}$ at $4^{\circ} \mathrm{C}$, and 2 washes in $1 \mathrm{ml}$ of PBS. Cells were then treated with a 1:2500 dilution of fluorescein isothiocyanate-conjugated goat anti-rabbit IgG (Jackson ImmunoResearch Laboratories Inc., West Grove, PA, USA) for $1 \mathrm{~h}$ at $4^{\circ} \mathrm{C}$, washed twice as before, resuspended in $500 \mu \mathrm{l}$ of PBS, and analyzed by FACS.

A similar experiment was set up with $3 \times 10^{6}$ cells per $100 \times 20 \mathrm{~mm}^{2}$ dish for analyzing protein expression. Cytosolic and membraneassociated proteins were extracted according to the Dignam method. ${ }^{71}$ Cells were removed at the same time points as described above.

\section{MTP}

To determine whether the mechanism by which compound $5 \mathrm{a}$ enhances TNF $\alpha$-induced apoptosis involves primarily the mitochondrion, we examined cells for changes in the MTP according to the method of Rottenberg and Wu. ${ }^{74}$ Briefly, 9D3S cells seeded at $2.5 \times 10^{5}$ per well in six-well plates in $3 \mathrm{ml}$ of normal medium in duplicate were incubated overnight. The wells were numbered 1-10. At time zero, cells in wells 3-4 and $7-8$ were treated with $0.2 \%$ DMSO, while those in wells 5-6 and 9-10 were treated with $200 \mathrm{nM} 5 \mathrm{a}$. At time $2 \mathrm{~h}$, cells in wells $7-10$ were treated with $20 \mathrm{ng}$ of TNF $\alpha$. At time $4 \mathrm{~h}$, cells were harvested, pelleted at $1000 \mathrm{rpm}$ for $5 \mathrm{~min}$, and resuspended in $200 \mu$ of PBS in $5 \mathrm{ml}$ polystyrene tubes. We then treated cells in tubes 3-10 (i.e. all except the untreated cells) with $25 \mathrm{nM} 3,3-$ dihexyloxacarbocyanine iodide $\left(\mathrm{DiOC}_{6}\right)$ solution for $20 \mathrm{~min}$ at $37^{\circ} \mathrm{C}$ in the dark. The reaction mixture was diluted with $400 \mu \mathrm{l}$ of PBS and analyzed for a decrease in the mitochondrion transmembrane potential by FACS using excitation wavelength at $484 \mathrm{~nm}$ and maximum emission wavelength at $501 \mathrm{~nm}$. 


\section{Animal study}

Athymic BALB/c nude mice (6-8 weeks old) were purchased from the National Cancer Institute, Frederick Cancer Research Facility (Frederick, MD, USA). They were housed under pathogen free conditions. The mice were allowed to acclimate for 2 weeks. Exponentially growing A375SM melanoma cells were harvested by trypsinization, washed once with $10 \mathrm{ml}$ of PBS, and injected into 30 athymic nude mice subcutaneously at $5 \times 10^{5}$ cells in $200 \times \mu$ l of PBS per animal as described previously. ${ }^{41}$ After 1 week, when mice had palpable tumors, three treatment groups consisting of 10 mice each were selected. The treatment groups consisted of nontreated control, $1 \mathrm{mg} 5 \mathrm{a}, 10 \mu \mathrm{g}$ TRAIL and $1 \mathrm{mg} 5 \mathrm{a}$ plus $10 \mu \mathrm{g}$ of TRAIL. One week after tumor injection, mice were injected intraperitoneally with $200 \mu$ of 5 a suspended in $25 \%$ DMSO in PBS or with $200 \mu$ of TRAIL dissolved in PBS, in the tail vein $1 \mathrm{~h}$ after the injection of $5 \mathrm{a}$ according to the treatment grouping. Daily injection was performed for 7 days. The length and width of tumors were measured with calipers every 2 days, and the volume was estimated by the formula: the square of the width $x$ length $\left(w^{2}\right)$. As a result of the limited available reagents, we could not sustain the treatment beyond 7 days.

After 7 days of treatment, the mice were kept for 11 more days for further observations. Tumor volumes continued to be measured as before. On day 18, all mice were sacrificed, and nonnecrotic tumors were removed from five mice from each treatment group. Representative sections were processed and stained for apoptotic cells using the TUNEL method, and for microvessel formation using anti-CD31 lgG as described previously. ${ }^{75}$

The data on tumor growth following different treatments were analyzed for statistical significance by the $t$-test (GraphPad Software Inc). The confidence limit was set at 0.95 .

\section{Acknowledgements}

We are grateful to Alisa Olarnpunsagoon for her technical support, Karen Ramirez for the FACS analysis, Patherine Greenwood for excellent preparation of this manuscript, and Walter Pagel for scientific editing of this manuscript. This work was supported in part by NIH Grants CA77055 (to ON) and CA76098 (to MB-E).

\section{References}

1. Catts VS, Farnsworth ML, Haber M, Norris MD, Lutze-Mann LH and Lock RB (2001) High level resistance to glucocorticoids, associated with a dysfunctional glucocorticoid receptor, in childhood acute lymphoblastic leukemia cells selected for methotrexate resistance. Leukemia 15: 929-935

2. Goldie JH (1994) Modelling the process of drug resistance Lung Cancer 10(Suppl 1):S91-S96

3. Burke PA, DeNardo SJ, Miers LA, Kukis DL and DeNardo GL (2002) Combined modality radioimmunotherapy Promise and peril. Cancer 94(Suppl 4): 1320-1331

4. Voelkel-Johnson C, King DL and Norris JS (2002) Resistance of prostate cancer cells to soluble TNF-related apoptosis-inducing ligand (TRAIL/Apo2L) can be overcome by doxorubicin or adenoviral delivery of full-length TRAIL. Cancer Gene Ther. 9: 164-172

5. Kemeny MM, Adak S, Gray B, Macdonald JS, Smith T Lipsitz S, Sigurdson ER, O'Dwyer PJ and Benson III AB (2002) Combined-modality treatment for resectable metastatic colorectal carcinoma to the liver: surgical resection of hepatic metastases in combination with continuous infusion of chemotherapy an intergroup study. J. Clin. Oncol. 20:1499-1505

6. Seiden MV, Ng SW, Supko JG, Ryan DP, Clark JW, Lynch T, Huang KC Kwiatkowski D, Skarin A and Eder Jr. JP (2002) A phase I clinical trial of sequentially administered doxorubicin and topotecan in refractory solid tumors. Clin. Cancer Res. 8: 691-697
7. Greco FA, Burris III HA, Litchy S, Barton JH, Bradof JE, Richards P, Scullin Jr., DC, Erland JB, Morrissey LH and Hainsworth JD (2002) Gemcitabine, carboplatin, and paclitaxel for patients with carcinoma of unknown primary site: a Minnie pearl Cancer Research Network Study. J. Clin. Oncol. 20: 1651-1666

8. Kirschmann DA, Seftor EA, Nieva DR, Mariano EA and Hendrix MJ (1999) Differentially expressed genes associated with the metastatic phenotype in breast cancer. Breast Cancer Res. Treat. 55: 127-136

9. Fidler I (1997) Molecular biology of cancer: invasion and metastasis. In Cancer: Principles and Practice of Oncology, DaVita Jr. V, Hellman S, Rosenberg S, eds. (Philadelphia: Lippincott-Raven Press)

10. Haas TL and Madri JA (1999) Extracellular matrix-driven matrix metalloproteinase production in endothelial cells: implications for angiogenesis. Trends Cardiovasc. Med. 9: 70-77

11. Kleiner DE and Stetler-Stevenson WG (1999) Matrix metalloproteinases and metastasis. Cancer Chemother. Pharmacol. 43(Suppl): S42-S51

12. Chang $C$ and Werb $Z$ (2001) The many faces of metalloproteases: cell growth, invasion, angiogenesis and metastasis. Trends Cell. Biol. 11: S37-S43

13. Monvoisin A, Bisson C, Si-Tayeb K, Balabaud C, Desmouliere A and Rosenbaum J (2002) Involvement of matrix metalloproteinase type-3 in hepatocyte growth factor-induced invasion of human hepatocellular carcinoma cells. Int. J. Cancer 97: 157-162

14. Mannello F and Gazzanelli G (2001) Tissue inhibitors of metalloproteinases and programmed cell death: conundrums controversies and potential implications. Apoptosis 6: 479-482

15. Lokeshwar BL, Selzer MG, Zhu BQ, Block NL and Golub LM. (2002) Inhibition of cell proliferation, invasion, tumor growth and metastasis by an oral nonantimicrobial tetracycline analog (COL-3) in a metastatic prostate cancer model. Int. J. Cancer 98: 297-309

16. Erlichman C, Adjei AA, Alberts SR, Sloan JA, Goldberg RM, Pitot HC, Rubin J, Atherton PJ, Klee GG and Humphrey R (2001) Phase I study of the matrix metalloproteinase inhibitor, BAY 12-9566. Ann. Oncol. 12: 389-395

17. Rudek MA, Figg WD, Dyer V, Dahut W, Turner ML, Steinberg SM, Liewehr DJ, Kohler DR, Pluda JM and Reed E (2001) Phase I clinical trial of oral COL-3, a matrix metalloproteinase inhibitor, in patients with refractory metastatic cancer. J. Clin. Oncol. 19: 584-592

18. Rosemurgy A, Harris J, Langleben A, Casper E, Goode $\mathrm{S}$ and Rasmussen $\mathrm{H}$ (1999) Marimastat in patients with advanced pancreatic cancer: a dose-finding study. Am. J. Clin. Oncol. 22: 247-252

19. Macaulay VM, O'Byrne KJ, Saunders MP, Braybrooke JP, Long L, Gleeson F, Mason CS, Harris AL, Brown P and Talbot DC (1999) Phase I study of intrapleural batimastat (BB-94), a matrix metalloproteinase inhibitor, in the treatment of malignant pleural effusions. Clin. Cancer Res. 5: 513-520

20. Wojtowicz-Praga S, Torri J, Johnson M, Steen V, Marshall J, Ness E, Dickson R, Sale M, Rasmussen HS, Chiodo TA and Hawkins MJ (1998) Phase I trial of Marimastat, a novel matrix metalloproteinase inhibitor, administered orally to patients with advanced lung cancer. J. Clin. Oncol. 16: 2150-2156.

21. Falardeau P, Champagne P, Poyet P, Hariton C and Dupont E (2001) Neovastat, a naturally occurring multifunctional antiangiogenic drug, in phase III clinical trials. Semin. Oncol. 28: 620-625

22. Haro H, Crawford HC, Fingleton B, Shinomiya K, Spengler DM and Matrisian LM (2001) Matrix metalloproteinase-7-dependent release of tumor necrosis factor-alpha in a model of herniated resorption. J. Clin. Invest. 105: 143-150.

23. Izumi $Y$, Hirata $M$, Hasuwa $H$, Iwamoto R, Umata $T$, Miyado $K$, Tamai $Y$, Kurisaki T, Sehara-Fujisawa A, Ohno S and Mekada E (1998) A metalloprotease-disintegrin, C9/meltrin-ADAM9 and PKC are involved in TPA-induced ectodomain shedding of membrane-anchored heparin-binding EGF-like growth factor. EMBO J. 17: 7260-7272

24. Dong J, Opresko LK, Dempsey PJ, Lauffenburger DJ, Coffey RJ and Wiley HS (1999) Metalloprotease-mediated ligand release regulates autocrine signaling through the epidermal growth factor receptor. Proc. Natl. Acad. Sci. USA. 96: 6235-6240

25. Raza SL and Cornelius LA (2000) Matrix metalloproteinases: pro- and antiangiogenic activities. J. Invest. Dermatol. Symp. Proc. 5:47-54

26. Madge LA, Sierra-Honigmann MR, Pober MR and Jordan S (1999) Apoptosisinducing agents cause rapid shedding of tumor necrosis factor receptor 1 (TNFR1). A nonpharmacological explanation for inhibition of TNF-mediated activation. J. Biol. Chem. 274: 13 643-13 649

27. Fernandez-Real JM, Lainez B, Vendrell J, Rigla M, Castro A, Penarroja G, Broch M, Perez A, Richart C, Engel P and Ricart W (2002) Shedding of TNF- 
alpha receptors, blood pressure and insulin sensitivity in type 2 diabetes mellitus. Am. J. Physiol. Endocrinol. Metab. 282: E952-E959.

28. Reddy P, Slack JL, Davis R, Cerretti DP, Kozlosky CJ, Blanton RA, Shows D, Peschon JJ and Black RA (2000) Functional analysis of the domain structure of tumor necrosis factor-alpha converting enzyme. J. Biol. Chem. 275: 14 608-14 614

29. Crowe PD, Walter BN, Mohler KM, Otten-Evans C, Black RA and Ware CF (1995) A metalloprotease inhibitor blocks shedding of the 80-kD TNF receptor and TNF processing in T lymphocytes. J. Exp. Med. 181: 1205-1210

30. Tamura Y, Watanabe F, Nakatani T, Yasui K, Fuji M, Komurasaki T, Tsuzuki H, Maekawa R, Yoshioka T, Kawada K, Sugita K and Ohtani M (1998) Highly selective and orally active inhibitors of type IV collagenase (MMP-9 and MMP2): $N$-sulfonylamino acid derivatives. J. Med. Chem. 41: 640-649

31. Ikeda M, Maekawa R, Tanaka H, Matsumoto M, Takeda Y, Tamura Y, Nemori $\mathrm{R}$ and Yoshioka $\mathrm{T}(2000)$ Inhibition of gelatinolytic activity in tumor tissues by synthetic matrix metalloproteinase inhibitor: application of film in situ zymography. Clin. Cancer Res. 6: 3290-3296

32. Nyormoi O, Wang Z, Doan D, Ruiz M, McConkey D and Bar-Eli M (2001) Transcription factor AP-2alpha is preferentially cleaved by caspase 6 and degraded by proteasome during tumor necrosis factor alpha-induced apoptosis in breast cancer cells. Mol. Cell. Biol. 21: 4856-4867

33. Kulms D and Schwarz T (2000) Molecular mechanisms of UV-induced apoptosis. Photodermatol. Photoimmunol. Photomed. 16: 195-201

34. Lucas M and Diaz P (2001) Thapsigargin-induced calcium entry and apoptotic death of neutrophils are blocked by activation of protein kinase. Pharmacology 63:191-196

35. Ojeda F, Folch H, Guarda MI, Jastorff B and Diehl HA (1995) Induction of apoptosis in thymocytes: new evidence for an interaction of PKC and PKA pathways. Biol. Chem. Hoppe Seyler 376: 389-393

36. Fan W (1999) Possible mechanisms of paclitaxel-induced apoptosis. Biochem. Pharmacol. 57: 1215-1221

37. Borset M, Hjorth-Hansen H, Johnsen AC, Seidel C, Waage A, Espevik T and Sundan A (1999) Apoptosis, proliferation and NF-kappaB activation induced by agonistic Fas antibodies in the human myeloma cell line $\mathrm{OH}-2$ : amplification of Fas-mediated apoptosis by tumor necrosis factor. Eur. J. Haematol. 63: 345-353

38. Thomas WD and Hersey P (1998) TNF-related apoptosis-inducing ligand (TRAIL) induces apoptosis in Fas ligand-resistant melanoma cells and mediates CD4 T cell killing of target cells. J. Immunol. 161: 2195-2200

39. Kishikawa T, Ghazizadeh M, Sasaki Y and Springer GF (1999) Specific role of $T$ and $T n$ tumor-associated antigens in adhesion between a human breast carcinoma cell line and a normal human breast epithelial cell line. Jpn. J. Cancer Res. 90: 326-332

40. Sliva D, Mason R, Xiao H and English D (2000) Enhancement of the migration of metastatic human breast cancer cells by phosphatidic acid. Biochem. Biophys. Res. Commun. 268: 471-479

41. Huang S, Jean D, Luca M, Tainsky MA and Bar-Eli M. (1998) Loss of AP-2 results in downregulation of $\mathrm{C}-\mathrm{KIT}$ and enhancement of melanoma tumorigenicity and metastasis. EMBO J. 273: 16501-16508

42. Nio Y, Zighelboim J, Berek J and Bonavida B (1990) Cycloheximide-induced modulation of TNF-mediated cytotoxicity in sensitive and resistant ovarian tumor cells. Cancer Chemother. Pharmacol. 26: 1-8

43. Jiang Y, Woronicz JD, Liu W and Goeddel DV (1999) Prevention of constitutive TNF receptor 1 signaling by silencer of death domains. Science 283: 543-546

44. Miki K and Eddy EM (2002). Tumor necrosis factor receptor 1 is an ATPase regulated by silencer of death domain. Mol. Cell. Biol. 22: 2536-2543

45. Hu S, Vincenz C, Ni J, Gentz R and Dixit VM (1997) I-FLICE, a novel inhibitor of tumor necrosis factor receptor-1- and CD-95-induced apoptosis. J. Biol. Chem. 272: $17255-11727$

46. Aggarwal BB, Singh S, LaPushin R and Totpal K (1995). Fas antigen signals proliferation of normal human diploid fibroblast and its mechanism is different from tumor necrosis factor receptor. FEBS Lett. 364: 5-8

47. Boldin MP, Mett IL, Varfolomeev EE, Chumakov I, Shemer-Avni Y, Camonis $\mathrm{JH}$, Wallach D (1995) Self-association of the "death domains" of the p55 tumor necrosis factor (TNF) receptor and Fas/APO1 prompts signaling for TNF and Fas/AP01 effects. J. Biol. Chem, 270: 387-391

48. Boldin MP, Goncharov TM, Goltsev YV and Wallach D (1996) Involvement of MACH, a novel MORT1/FADD-interacting protease, in Fas/APO-1- and TNF receptor-induced cell death. Cell 85: 803-815
49. Duan $\mathrm{H}$ and Dixit VM (1997) RAIDD is a new 'death' adaptor molecule. Nature 385:86-89

50. Stennicke HR and Salvesen GS (1997) Biochemical characteristics of caspases-3, -6, -7, and -8. J. Biol. Chem. 272: 25719-25723

51. Pan G, Ni J, Wei YF, Yu G, Gentz R and Dixit VM (1997) An antagonist decoy receptor and a death domain-containing receptor for TRAIL. Science 277 815-818

52. Sheridan JP, Marsters SA, Pitti RM, Gurney A, Skubatch M, Baldwin D, Ramakrishnan L, Gray CL, Baker K, Wood WI, Goddard AD, Godowski P and Ashkenazi A (1997) Control of TRAIL-induced apoptosis by a family of signaling and decoy receptors. Science 277: 818-821

53. Cai J, Yang J and Jones DP (1998) Mitochondrial control of apoptosis: the role of cytochrome $c$. Biochim. Biophys. Acta 1366: 139-149

54. Guo Y, Srinivasula SM, Druilhe A, Fernandes-Alnemri T and Alnemri ES (2002) Caspase-2 induces apoptosis by releasing proapoptotic proteins from mitochondria. J. Biol. Chem. 277: 13430-11347

55. Du C, Fang M, Li Y, Li L and Wang X (2000) Smac, a mitochondrial protein that promotes cytochrome $c$-dependent caspase activation by eliminating IAP inhibition. Cell 102: 33-42

56. Gruss HJ (1996) Molecular, structural, and biological characteristics of the tumor necrosis factor ligand superfamily. Int. J. Clin. Lab. Res. 26: $143-159$

57. Cohen, GM (1997) Caspases: the executioners of apoptosis. Biochem. J. 326:1-16

58. Earnshaw WC, Martins LM and Kaufmann SH (1999) Mammalian caspases: Structure, activation, substrates, and functions during apoptosis. Ann. Rev. Biochem. 68: 383-424

59. Ambrosini G, Adida C and Altieri DC (1997) A novel anti-apoptosis gene, survivin, expressed in cancer and lymphoma. Nat. Med. 3:917-921

60. Coussens LM, Fingleton B and Matrisian LM (2002) Matrix metalloproteinase inhibitors and cancer - trials and tribulations. Science 295: 2387-2392

61. Li H, Lindenmeyer F, Grenet C, Opolon P, Menashi S, Soria C, Yeh P, Perricaudet M and Lu H (2001) AdTIMP-2 inhibits tumor growth, angiogenesis, and metastasis, and prolongs survival in mice. Hum. Gene Ther. 12 : 515-526

62. Nakamura $\mathrm{Y}$, Sato K, Wakimoto N, Kimura F, Okuyama A and Motoyoshi K (2001) A new matrix metalloproteinase inhibitor SI-27 induces apoptosis in several human myeloid leukemia cell lines and enhances sensitivity to TNF alpha-induced apoptosis. Leukemia 15: 1217-1224

63. Shalinsky DR, Brekken J, Zou H, McDermott CD, Forsyth P, Edwards D, Margosiak S, Bender S, Truitt G, Wood A, Varki NM and Appelt K (1999) Broad antitumor and antiangiogenic activities of $A G 3340$, a potent and selective MMP inhibitor undergoing advanced oncology clinical trials. Ann. N Y Acad. Sci. 878: 236-270

64. Erba E, Ronzoni S, Bassano L, Giavazzi R and D'Incalci M (1999) The metalloproteinase inhibitor batimastat (BB-94) causes cell cycle phase perturbations in ovarian cancer cells. Ann. Oncol. 10: 589-591

65. Daniel C, Duffield J, Brunner T, Steinmann-Niggli K, Lods N and Marti H-P (2001) Matrix metalloproteinase inhibitors cause cell cycle arrest and apoptosis in glomerular mesangial cells. J. Pharmacol. Exp. Ther. 297: $57-68$

66. Rokhlin OW, Guseva NV, Tagiyev AF, Glover RA and Cohen MB. (2002) Caspase-8 activation is necessary but not sufficient for tumor necrosis factorrelated apoptosis-inducing ligand (TRAIL)-mediated apoptosis in the prostatic carcinoma cell line LNCaP. Prostate 52: 1-11

67. Srivastava RK (2001) TRAIL/Apo-2L: Mechanisms and clinical applications in cancer. Neoplasia 3: 535-546

68. Wu X, He Y, Falo Jr. LD, Hui KM and Huang L (2001) Regression of human mammary adenocarcinoma by systemic administration of a recombinant gene encoding the hFlex-TRAIL fusion protein. Mol. Ther. 3: 368-374

69. Ichikawa K, Liu W, Zhao L, Wang Z, Liu D, Ohtsuka T, Zhang H, Mountz JD, Koopman WJ, Kimberly RP and Zhou T (2001) Tumoricidal activity of a novel anti-human DR5 monoclonal antibody without hepatocyte cytotoxicity. Nat. Med. 7: 954-960

70. Kelley SK, Harris LA, Xie D, Deforge L, Totpal K, Bussiere J and Fox JA (2001) Preclinical studies to predict the disposition of Apo2L/tumor necrosis factor-related apoptosis-inducing ligand in humans: characterization of in vivo efficacy, pharmacokinetics, and safety. J. Pharmacol. Exp. Ther. 299: $31-38$ 
71. Dignam JD, Lebovitz M and Roeder RG (1983) Accurate transcription initiation by RNA polymerase II in a soluble extract from isolated mammalian nuclei. Nucleic Acids Res. 11: 1475-1489

72. Nyormoi O, Schneider T and Smith RG (1994) A large scale preparative gel electrophoresis separation of alpha 1 and alpha 2 subunits of the voltage-gated $\mathrm{Ca} 2+$ channel from rabbit skeletal muscle. Electrophoresis 15 : $1186-1190$

73. Nyormoi $O$ (1996) Proteolytic activity in amylotrophic lateral sclerosis $\lg G$ preparations. Ann. Neurol. 40: 701-706
74. Rottenberg H and Wu S (1998) Quantitative assay by flow cytometry of the mitochondrial membrane potential in intact cells. Biochim. Biophys. Acta 1404: 393-404

75. Huang S, Mills L, Mian B, Tellez C, McCarty M, Yang XD, Gudas JM and Bar-Eli $M$ (2002) Fully humanized neutralizing antibodies to interleukin-8 (ABX-IL8) inhibit angiogenesis, tumor growth, and metastasis of human melanoma. Am. J. Pathol. 161: 125-134 